\title{
EVALUASI PERTUMBUHAN AWAL JABON (Neolamarckia cadamba Roxb) DI HUTAN RAKYAT
}

\author{
(Early Growth Evaluation of Neolamarckia cadamba Roxb at Private Forest) \\ Lutfy Abdulah, Nina Mindawati, A. Syaffari Kosasih, Darwo \\ Pusat Litbang Peningkatan Produktivitas Hutan \\ Kampus Balitbang Kehutanan, Jl. Gunung Batu No. 5 Po.Box 331, Bogor 16610, Indonesia \\ Email: lutfyabdulah@yahoo.co.id, ninapulp@gmail.com, safari_silvik@yahoo.com,darwo_iph@yahoo.co.id
}

Naskah masuk : 23 Januari 2013; Naskah diterima : 10 Juli 2013

\begin{abstract}
Neolamarckia cadamba Roxb.(Jabon) is one of the fast-growing tree species, so it is very desirable to be developed in community forests and plantation forests. However, understanding of silvicultural techniques such as nutrient management at the site is necessary to achieve optimal growth. In addition, land areas for community forests are limited. In other hand, adequate land areas for crops cultivation are also important. This research was designed to study the growth rate of Neolamarckia cadamba Roxb. at various scenario management to improve economic land value. Those scenarios were Jabon plantation fertilized with compost, Jabon were planted by means of agroforestry system with compost fertilizer and without compost fertilizer. The initial growth rate of Jabon was observed. The method used was a completely randomized design. The results showed that the highest diameter growth of the trees were reflected by the seedlings which were planted in agroforestry patterns with and without compost fertilizer. While the highest growth in height were reflected by the trees planted at agroforestry patterns with compost fertilizer.
\end{abstract}

Keywords: Neolamarckia cadamba Roxb, agroforestry, fertilization, early growth, private forest

\begin{abstract}
ABSTRAK
Jabon merupakan salah satu jenis pohon cepat tumbuh, sehingga jabon sangat diminati untuk dikembangkan di hutan rakyat dan hutan tanaman industri. Namun, pertumbuhan yang optimal akan tercapai jika pemahaman tentang teknik silvikultur seperti manajemen hara di tapak sangat dibutuhkan. Selain itu, luas lahan milik yang diperuntukkan untuk membangun hutan rakyat tidak terlalu luas, sementara kebutuhan untuk budidaya tanaman hortikultura juga penting. Untuk itu penelitian ini dirancang untuk mempelajari laju pertumbuhan jabon pada scenario pengelolaan antara manajemen hara dan pemanfaatan lahan antara untuk meningkatkan nilai ekonomi lahan.Penelitian ini bertujuan untuk melihat beda pertumbuhan awal jabon pada variasi manajemen lahan dan manajemen hara yang berbeda terutama pemupukan dan pola agroforestry yang dikembangkan. Metode yang digunakan adalah rancangan acak lengkap, dimana perlakuan yang dilakukan adalah penanaman jabon dengan diberi pupuk kompos, jabon ditanam dengan pola agroforestry dan tidak diberi pupuk kompos serta jabon ditanam dengan pola agroforestry dan diberi pupuk kompos.Hasil penelitian menunjukkan bahwa pertumbuhan diameter jabon terbaik bila jabon ditanam dengan pola agroforestry dan tidak diberi pupuk kompos maupun jabon ditanam dengan pola agroforestry dan diberi pupuk kompos.Sementara perlakuan terbaik untuk pertumbuhan tinggi jabon adalah jabon ditanam dengan pola agroforestry dan diberi pupuk kompos.
\end{abstract}

Kata kunci : Jabon, agroforestry, pupuk, pertumbuhan awal, hutan rakyat

\section{PENDAHULUAN}

\section{A. Latar Belakang}

Laju pertumbuhan hutan rakyat di Pulau Jawa terus meningkat mencapai 2,8 juta hektar, Kementerian Kehutanan (2011), dan merupakan bagian penting dalam upaya pemenuhan bahan baku kayu dan pengembangan ekonomi rakyat. Petani cenderung menanami pekarangan, tegalan dan bagian lahan milik dengan tanaman hutan (Ekawati et al., 2005). Jenis tanaman hutan yang sering ditanam tergolong dalam kelompok jenis pohon cepat tumbuh (fast growing species) seperti jabon (Neolamarckia cadamba Roxb) dan sengon (Falcataria mollucana). 
Jabon termasuk dalam famili Rubiaceae yang merupakan jenis cepat tumbuh dan butuh cahaya penuh (light-demanding). Jabon dapat dipanen pada umur 5 tahun dengan diameter rata-rata jabon mencapai 25,3 cm dan tinggi mencapai 17,1 meter (Krisnawati et al., 2011). Bentuk batang jabon adalah lurus dan silindris. Jabon ditemukan tumbuh secara alami di wilayah Sulawesi bagian Utara, dan Maluku. Jabon tumbuh pada daerah yang baru dibuka, sehingga bersifat pionir. Penanaman jabon mudah dikerjakan, mudah mendapatkan benih dalam jumlah yang banyak serta tidak ada hambatan dalam pengadaan bibit secara besar-besaran (Martawijaya et al., 1989). Dari segi manfaatnya, kayu jabon dapat digunakan untuk bahan baku kayu lapis, konstruksi ringan, lantai, pulp dan kertas, langit-langit, kotak, peti, mainan, ukiran, korek api, sumpit dan pensil (Martawijaya et al., 1989).

Meskipun jabon dapat tumbuh mudah di lapangan, perlu dilakukan kajian aspek silvikultur bila jabon ditanam di lokasi lain yang bukan habitat alaminya. Kajian aspek silvikultur diharapkan mampu memberikan informasi manipulasi lingkungan yang sesuai sehingga jabon dapat tumbuh baik, memberikan manfaat ekonomi yang tinggi serta manfaat ekologi. Kajian silvikultur yang sesuai adalah dapat memenuhi kebutuhan hara tanaman dan mampu meningkatkan nilai ekonomi lahan. Untuk itu penelitian ini dilakukan untuk mengetahui respon pertumbuhan jabon terhadap pemupukan yang dikombinasikan dengan pola agroforestry.

\section{METODE PENELITIAN}

\section{A. Lokasi dan Waktu Penelitian}

Penelitian dilakukan di Desa Girimulya, Kecamatan Cibeber, Kabupaten Cianjur, Jawa Barat. Pengukuran pertumbuhan dilakukan sejak bulan September 2009 sampai dengan bulan Nopember 2011.

\section{B. Bahan dan Alat}

Bahan yang digunakan dalam penelitian ini adalah bibit jabon yang berasal dari PT. Silva Tropika yang ditanam pada umur 4 bulan.Alat yang digunakan dalam penelitian ini adalah caliper untuk mengukur diameter pohon setinggi dada, mistar tinggi untuk mengukur tinggi total individu pohon, kompas untuk mengetahui arah penanaman dan SPSS versi 16 untuk analisis data statistik.

\section{Perlakuan}

Penelitian dilakukan pada lahan seluas $50 \mathrm{Ha}$ di hutan rakyat jabon yang ditanam dengan jarak tanam $3 \times 3$ m dan tiga perlakuan sebagai berikut:

1. Perlakuan pertama adalah pemupukan organik dengan pupuk kandang $2 \mathrm{~kg} /$ tanaman dan dikombinasikan dengan pola pengelolaan lahan agroforestry. Penerapan pola agroforestry secara intensif sampai tanaman berumur 18 bulan dengan menanam cabe, jagung, sawi, bawang daun dan timun.

2. Perlakuan kedua adalah tanaman jabon diberi pupuk dasar kotoran ayam $2 \mathrm{~kg} / \mathrm{tanaman}$ tanpa agroforestry.

3. Perlakuan ketiga adalah tanaman jabon tidak diberi pupuk kandang melainkan ditanam dengan pola agroforestry dengan pemupukan yang intensif pada tanaman pertanian sampai umur 23 bulan. Setiap perlakuan diulang sebanyak 4 kali.

Pengamatan pada plot berukuran $30 \times 20 \mathrm{~m}$ yang dilakukan setiap 6 bulan sekali setelah penanaman sampai umur 24 bulan. Pengukuran diameter pohon dilakukan dengan menggunakan caliper pada ketinggian setinggi dada, sedangkan tinggi pohon diukur dengan menggunakan mistar tinggi.

\section{Analisis Data}

Hasil pengukuran dianalisis dengan menggunakan metode analisis data Rancangan Acak Lengkap (RAL). Analisis RAL dilakukan pada beberapa variabel respon berbeda, yakni jumlah pohon pada setiap pengukuran, diameter dan tinggi. Bentuk umum model linier aditif (Mattjik dan Sumertajaya, 2006) sebagai berikut:

$$
Y_{i j}=\mu+\tau_{i}+\varepsilon_{i j}
$$

dimana i sebagai perlakuan ke $1,2,3, \ldots$, , dan $j$ sebagai ulangan dari $1,2, \ldots$, r. $Y_{\mathrm{ij}}$ menunjukkan pengamatan pada perlakuan ke-i dan ulangan ke$\mathrm{j}$, notasi $\mu$ menunjukkan rataan umum dan notasi $\tau$ menunjukkan pengaruh perlakuan ke-i, atau dapat ditunjukkan dengan $\mu \mathrm{i}-\mu$. $\varepsilon_{\mathrm{ij}}$ menunjukkan pengaruh acak pada perlakuan ke-i dan ulangan ke-j. 


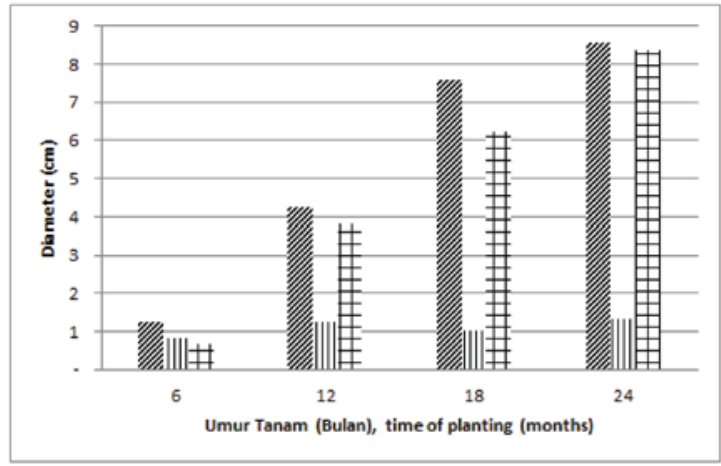

Keterangan (Remarks) :

IIII : Perlakuan pemupukan kandang $2 \mathrm{~kg}$ dan agroforestry (2 $\mathrm{kg}$ of organic fertilizer and agroforestry)

III: : Perlakuan pemupukan kandang $2 \mathrm{~kg}$ (2 kg of organic fertilizer without agroforestry)

王 : Agroforestry

Gambar(Figure) 1. Rata-rata pertumbuhan diameter jabon pada setiap pengukuran (Mean of diameter growth in each measurement)

\section{HASIL DAN PEMBAHASAN}

\section{A. Hasil Penelitian}

Pada umur 2 tahun, diameter rata-rata untuk tanaman jabon yang diberi pupuk kandang sebanyak $2 \mathrm{~kg} /$ tanaman dan agroforestry adalah $8,56 \mathrm{~cm}$, sedangkan diameter rata-rata tanaman yang diberi pupuk kandang sebanyak $2 \mathrm{~kg} /$ tanaman tanpa agroforestry adalah $1,36 \mathrm{~cm}$ dan pada tanaman yang tidak dipupuk namun ditanam dengan teknik agroforestry adalah $8,38 \mathrm{~cm}$.

Pada umur 2 tahun, tinggi rata-rata untuk tanaman yang diberi pupuk kandang sebanyak $2 \mathrm{~kg} /$ tanaman dan agroforestry adalah 532,28 cm, sedangkan tinggi rata-rata tanaman yang diberi pupuk kandang sebanyak $2 \mathrm{~kg} /$ tanaman tanpa agroforestry adalah $88,08 \mathrm{~cm}$ dan tinggi rata-rata tanaman yang tidak dipupuk namun ditanam dengan teknik agroforestry adalah $394,33 \mathrm{~cm}$.

\section{Pertumbuhan diameter}

Pertumbuhan diameter pada masing-masing perlakuan berbeda. Perbedaan pertumbuhan terjadi pada saat tegakan berumur 6 bulan sampai dengan berumur 24 bulan sebagaimana disajikan pada Gambar 1.

Berdasarkan Gambar 1, pada umur 6 bulan pertumbuhan diameter jabon dengan perlakuan pupuk kandang sebesar $2 \mathrm{~kg} /$ tanaman dan agroforestry lebih baik dibandingkan 2 perlakuan lain. Diameter umur 6 bulan untuk jabon yang dipupuk dengan pupuk kandang $2 \mathrm{~kg}$ lebih baik dibandingkan jabon yang tidak dipupuk. Hal ini disebabkan oleh pupuk kandang sebesar $2 \mathrm{~kg} /$ tana- man mengakibatkan tanah lebih poros sehingga tanaman tumbuh lebih cepat jika tidak dipupuk sama sekali. Pada umur 12 bulan, diameter jabon yang dipupuk dengan pupuk kandang $2 \mathrm{~kg} / \mathrm{tana}-$ man serta agroforestry mencapai $5 \mathrm{~cm}$ dan lebih baik dibandingkan jabon yang hanya dipupuk dengan pupuk kandang tanpa agroforestry. Pada umur 18 bulan, diameter jabon yang dipupuk kandang $2 \mathrm{~kg} /$ batang dan diolah dengan sistem agroforestry mencapai $9 \mathrm{~cm}$ lebih baik dari jabon yang diberi perlakuan pupuk kandang saja atau diolah dengan sistem agroforestry tanpa diberi pupuk kandang. Pada umur 24 bulan, pertumbuhan diameter jabon yang dipupuk dengan pupuk kadang $2 \mathrm{~kg} /$ tanaman dan diolah dengan sistem agroforestry sama dengan jabon yang tidak dipupuk namun diolah dengan sistem agroforestry. Terdapat perbedaan pengaruh pupuk kandang dan sistem pengolahan tanah terhadap diameter. Untuk itu dilakukan diuji beda tumbuh diameter sebagaimana disajikan pada Tabel 1.

Berdasarkan hasil ANOVA di atas terlihat bahwa pada umur 6 bulan sampai dengan umur 24 bulan, perilaku pertumbuhan diameter jabon berbeda nyata. Hal ini menunjukkan bahwa perlakuan pemupukan dan pengolahan tanah berpengaruh nyata terhadap pertumbuhan diameter, sehingga pemberian pemupukan intensif di hutan rakyat harus diikuti dengan teknik pengolahan lahan yang tepat salah satunya dengan sistem agroforestry. Selanjutnya dapat diuji dengan menggunakan uji lanjut Duncan dan hasilnya disajikan pada Tabel 2. 
Tabel (Table)1. Uji beda nyata pertumbuhan diameter jabon (Analysis of variace of diameters growth)

\begin{tabular}{|c|c|c|c|c|c|c|c|}
\hline $\begin{array}{l}\text { Umur } \\
(\mathrm{Age})\end{array}$ & $\begin{array}{c}\text { Sumber } \\
\text { keragaman } \\
\text { (Source of } \\
\text { variance) }\end{array}$ & $\begin{array}{l}\text { Derajat } \\
\text { bebas } \\
\text { (Degree of } \\
\text { freedom) }\end{array}$ & $\begin{array}{l}\text { Jumlah } \\
\text { kuadrat } \\
\text { (Sum of } \\
\text { square) }\end{array}$ & $\begin{array}{l}\text { Rata-rata } \\
\text { kuadrat } \\
\text { (Mean of } \\
\text { square) } \\
\end{array}$ & F-Hitung & Sig. & $\mathrm{R}$ \\
\hline \multirow[t]{5}{*}{6 Bulan } & Corrected Model & $.695^{\mathrm{a}}$ & 2 & ,348 & 8.992 & .007 & 0,666 \\
\hline & Intersep & 10.379 & 1 & 10,379 & 268.572 & .000 & \\
\hline & Perlakuan & .695 & 2 & ,348 & 8.992 & .007 & \\
\hline & Error & .348 & 9 & 039 & & & \\
\hline & Total & 11.422 & 12 & & & & \\
\hline \multirow[t]{5}{*}{12 Bulan } & Corrected Model & $21.074^{\mathrm{a}}$ & 2 & 10,537 & 23.761 & .000 & 0,805 \\
\hline & Intercept & 116.688 & 1 & 116,688 & 263.130 & .000 & \\
\hline & Perlakuan & 21.074 & 2 & 10,537 & 23.761 & .000 & \\
\hline & Error & 3.991 & 9 & ,443 & & & \\
\hline & Total & 141.753 & 12 & & & & \\
\hline \multirow[t]{5}{*}{18 Bulan } & Corrected Model & $96.054^{\mathrm{a}}$ & 2 & 48,027 & 48.576 & .000 & 0,915 \\
\hline & Intercept & 295.616 & 1 & 295,616 & 298.991 & .000 & \\
\hline & Perlakuan & 96.054 & 2 & 48,027 & 48.576 & .000 & \\
\hline & Error & 8.898 & 9 & ,989 & & & \\
\hline & Total & 400.569 & 12 & & & & \\
\hline \multirow[t]{5}{*}{24 Bulan } & Corrected Model & $134.913^{\mathrm{a}}$ & 2 & 67,456 & 60.302 & .000 & 0,931 \\
\hline & Intercept & 446.642 & 1 & 446,642 & 399.272 & .000 & \\
\hline & Perlakuan & 134.913 & 2 & 67,456 & 60.302 & .000 & \\
\hline & Error & 10.068 & 9 & 1,119 & & & \\
\hline & Total & 591.622 & 12 & & & & \\
\hline
\end{tabular}

Tabel (Table) 2. Uji lanjut Duncan (Duncan test)

\begin{tabular}{cccc}
\hline $\begin{array}{c}\text { Pengukuran } \\
\text { (Measurement } \\
\text { periods })\end{array}$ & $\begin{array}{c}\text { Pupuk kandang +agroforestry } \\
(\text { Organic fertilizer and } \\
\text { agroforestry) }\end{array}$ & $\begin{array}{c}\text { Pupuk kandang } \\
\text { (Organic fertilizer) }\end{array}$ & Agroforestry \\
\hline 6 Bulan & $\mathrm{a}$ & $\mathrm{b}$ & $\mathrm{b}$ \\
12 Bulan & $\mathrm{a}$ & $\mathrm{b}$ & $\mathrm{a}$ \\
18 Bulan & $\mathrm{a}$ & $\mathrm{b}$ & $\mathrm{a}$ \\
24 Bulan & $\mathrm{a}$ & $\mathrm{b}$ & $\mathrm{a}$ \\
\hline
\end{tabular}

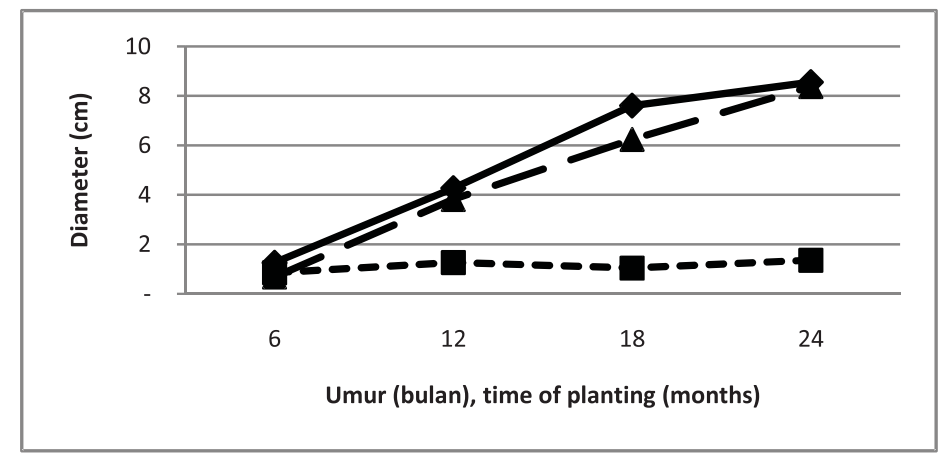

Keterangan (Remarks) :

- Perlakuan pemupukan kandang $2 \mathrm{~kg}$ dan agroforestry ( $2 \mathrm{~kg}$ of organic fertilizer and agroforestry)

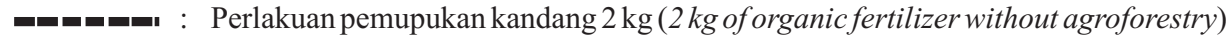

- $=$ : Agroforestry

Gambar (Figure) 2. Pola pertumbuhan diameter jabon (Pattern of diameter growth) 
Berdasarkan Tabel 3 dapat dilihat bahwa perlakuan pemupukan dengan pupuk kandang dan agroforestry pada awalnya memberikan pengaruh yang berbeda dengan perlakuan lainnya. Namun pada umur 12 sampai 24 bulan, pertumbuhan diameter jabon dengan perlakuan pupuk kandang dan agroforestry akan sama dengan pertumbuhan diameter jabon jika hanya diolah lahannya dengan sistem agroforestry.

Pemupukan dan pola pengolahan tanah dengan sistem agroforestry sangat mempengaruhi pertumbuhan diameter jabon. Jika pada awal penanaman hanya dipupuk saja maka pertumbuhan diameter di umur berikutnya tidak lebih besar dibandingkan jabon yang dipupuk dengan pupuk kandang dan tanahnya diolah dengan sistem agroforestry. Hal ini dapat dilihat pada Gambar 2.

Gambar 2 menunjukkan bahwa diameter jabon akan tumbuh baik bila pada awal penanaman diberi pupuk kandang sebanyak $2 \mathrm{~kg} / \mathrm{batang}$ dan dilakukan pola agroforestry atau jika ada tanaman musim yang ditanam bersama jabon. Pada pola agroforestry, pemupukan dapat terjadi di tanaman jabon saja atau tanaman semusim saja atau keduanya. Hal ini akan memacu pertumbuhan diameter jabon.

\section{Beda pertumbuhan tinggi}

Pertumbuhan tinggi yang terjadi pada tanaman jabon setelah dipupuk dengan pupuk kandang $2 \mathrm{~kg} /$ tanaman dan agroforestry cenderung lebih tinggi dibandingkan dengan tanaman jabon yang dipupuk dengan pupuk kandang sebanyak $2 \mathrm{~kg} /$ tanaman atau jabon yang ditanam dengan pola agroforestry. Hal ini dapat dilihat pada Gambar 3 berikut.

Berdasarkan Gambar 3, pada umur 6 bulan pertumbuhan tinggi jabon dengan perlakuan pupuk kandang sebesar $2 \mathrm{~kg} /$ tanaman dan agroforestry lebih baik dibandingkan 2 perlakuan lain. Tinggi umur 6 bulan untuk jabon yang dipupuk dengan pupuk kandang $2 \mathrm{~kg}$ lebih baik diban-dingkan jabon yang tidak dipupuk. Pada umur 12 bulan, tinggi jabon yang dipupuk dengan pupuk kandang $2 \mathrm{~kg} /$ tanaman serta agroforestry men-capai $350 \mathrm{~cm}$ dan lebih baik dibandingkan jabon yang hanya dipupuk dengan pupuk kandang tan-pa agroforestry.

Pada umur 18 bulan, tinggi jabon yang dipupuk kandang $2 \mathrm{~kg} / \mathrm{batang}$ dan diolah dengan sistem agroforestry mencapai $600 \mathrm{~cm}$ lebih baik dari jabon yang diberi perlakuan pupuk kandang saja atau diolah dengan sistem agroforestry tanpa diberi pupuk kandang. Terdapat perbedaan pengaruh pupuk kandang terhadap tinggi.Untuk itu dilakukan diuji beda tumbuh tinggi sebagaimana disajikan pada Tabel 3.

Berdasarkan ANOVA di atas terlihat bahwa pertumbuhan tinggi jabon berbeda berdasarkan jenis perlakuan pada pengolahan lahan. Pemberian pupuk kandang di awal penanaman dan diteruskan dengan pemupukan lanjutan sehingga pertumbuhan tinggi lebih baik. Hal ini didukung

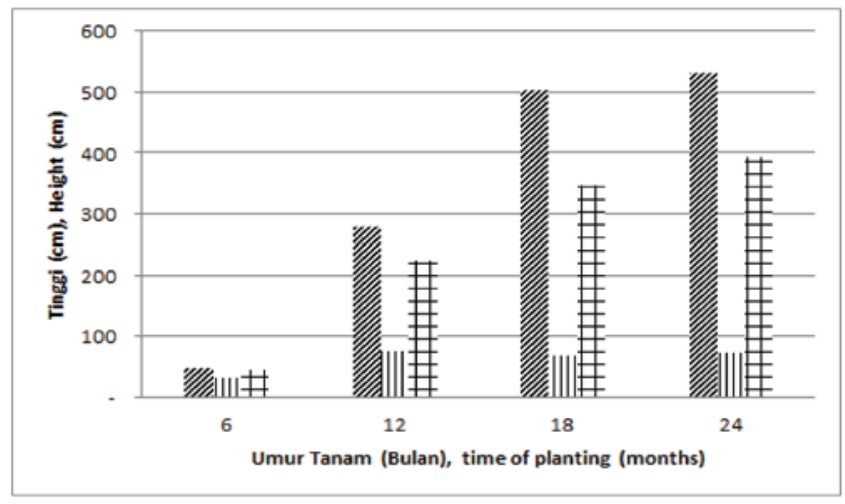

Keterangan (Remarks) :

IIII : Perlakuan pemupukan kandang $2 \mathrm{~kg}$ dan agroforestry (2 $\mathrm{kg}$ of organic fertilizer and agroforestry)

III: : Perlakuan pemupukan kandang $2 \mathrm{~kg}$ (2 kg of organic fertilizer without agroforestry)

王：Agroforestry

Gambar(Figure)3. Rata-rata pertumbuhan tinggi jabon pada setiap pengukuran (Mean of height growth) 
Tabel (Table) 3. Uji beda nyata pertumbuhan tinggi jabon (Analysis of variance of height growth)

\begin{tabular}{|c|c|c|c|c|c|c|c|}
\hline $\begin{array}{l}\text { Umur } \\
(\text { Age })\end{array}$ & $\begin{array}{l}\text { Sumber keragaman } \\
\text { (Source of variance) }\end{array}$ & $\begin{array}{c}\text { Derajat bebas } \\
\text { (Degree of } \\
\text { freedom) }\end{array}$ & $\begin{array}{l}\text { Jumlah } \\
\text { kuadrat } \\
\text { (Sum of } \\
\text { square) }\end{array}$ & $\begin{array}{l}\text { Rata-rata } \\
\text { kuadrat } \\
\text { (Means of } \\
\text { square) }\end{array}$ & F-Hitung & Sig. & $\mathrm{R}$ \\
\hline \multirow[t]{5}{*}{6 Bulan } & Corrected Model & $607,374^{\mathrm{a}}$ & 2 & 303,687 & 5,415 & ,029 & 0,54 \\
\hline & Intercept & 23927,935 & 1 & 23927,93 & 426,635 &, 000 & \\
\hline & Perlakuan & 607,374 & 2 & 303,687 & 5,415 & 029 & \\
\hline & Error & 504,767 & 9 & 56,085 & & & \\
\hline & Total & 25040,077 & 12 & & & & \\
\hline \multirow[t]{5}{*}{12 Bulan } & Corrected Model & $88294,881^{\mathrm{a}}$ & 2 & 44147,44 & 15,666 &, 001 & 0,77 \\
\hline & Intercept & 460666,697 & 1 & 460666,7 & 163,469 &, 000 & \\
\hline & Perlakuan & 88294,881 & 2 & 44147,44 & 15,666 & 001 & \\
\hline & Error & 25362,649 & 9 & 2818,072 & & & \\
\hline & Total & 574324,227 & 12 & & & & \\
\hline \multirow[t]{5}{*}{18 Bulan } & Corrected Model & $384416,147^{\mathrm{a}}$ & 2 & 192208,1 & 29.036 &, 000 & 0,87 \\
\hline & Intercept & 1134847,20 & 1 & 1134847 & 171.435 &, 000 & \\
\hline & Perlakuan & 384416,147 & 2 & 192208,1 & 29.036 & 000 & \\
\hline & Error & 59577,135 & 9 & 6619,682 & & & \\
\hline & Total & 1578840,5 & 12 & & & & \\
\hline \multirow[t]{5}{*}{24 Bulan } & Corrected Model & $438611,416^{\mathrm{a}}$ & 2 & 219305,7 & 32.177 &, 000 & 0,88 \\
\hline & Intercept & 1339607,36 & 1 & 1339607 & 196.553 &, 000 & \\
\hline & Perlakuan & 438611,416 & 2 & 219305,7 & 32.177 &, 000 & \\
\hline & Error & 61339,565 & 9 & 6815,507 & & & \\
\hline & Total & 1839558,34 & 12 & & & & \\
\hline
\end{tabular}

Tabel (Table) 4. Uji Lanjut Duncan (Duncan test)

\begin{tabular}{lccc}
\hline \multirow{2}{*}{$\begin{array}{c}\text { Pengukuran } \\
\text { Measurement periods) }\end{array}$} & \begin{tabular}{c} 
Perlakuan (treatment) \\
\cline { 2 - 4 }
\end{tabular} & $\begin{array}{c}\text { Pupuk kandang + agroforestry } \\
\text { (organic fertilizer and agroforestry) }\end{array}$ & Agroforestry \\
\hline 6 Bulan (months) & $\mathrm{a}$ & $\mathrm{a}$ & $\mathrm{a}$ \\
12 Bulan (months) & $\mathrm{a}$ & $\mathrm{a}$ & $\mathrm{a}$ \\
18 Bulan (months) & $\mathrm{a}$ & $\mathrm{c}$ & $\mathrm{b}$ \\
24 Bulan (months) & $\mathrm{a}$ & $\mathrm{c}$ & $\mathrm{b}$ \\
\hline
\end{tabular}

Keterangan(Remarks): a. Perlakuan terbaik(Best treatment)

b. Perlakuan baik (Good treatment)

c. Perlakuan kurang baik (Not good treatment)

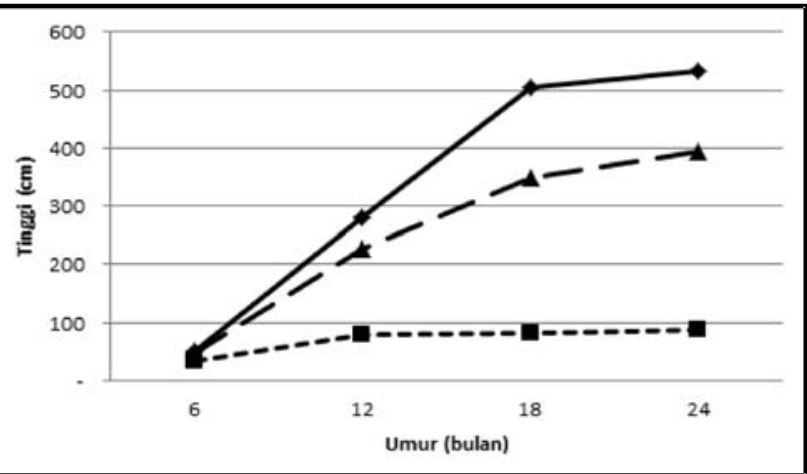

Keterangan : $\quad$ Perlakuan pemupukan kandang $2 \mathrm{~kg}$ dan agroforestry $(2 \mathrm{~kg}$ of organic fertilizer and agroforestry)

ישטשט : Perlakuan pemupukan kandang $2 \mathrm{~kg}$ (2 kg of organic without fertilizer and agroforestry)

$\square$ : agroforestry

Gambar (Figure) 4. Pola pertumbuhan tinggi jabon (Height growth pattern) 
oleh uji lanjut Duncan sebagaimana disajikan pada Tabel 4.

Berdasarkan hasil uji lanjut Duncan di atas terlihat bahwa pada umur 6 bulan, pemberian pupuk kandang dan lahan diolah dengan sistem agroforestry dan jabon yang tidak dipupuk dengan pupuk kandang namun lahannya diolah dengan sistem agroforestry akan memberikan pengaruh pada pertumbuhan yang tinggi dibandingkan jabon hanya dipupuk saja tanpa lahannya diolah dengan sistem agroforestry. Namun, pada umur 12 bulan atau 1 tahun, perilaku pertumbuhan tinggi sama dengan kondisi pada saat6 bulan dimana pertumbuhan tinggi jabon dengan dipupuk kandang $2 \mathrm{~kg} /$ batang dan diolah dengan pola agroforestry sama dengan jabon yang ditanam tanpa pupuk namun diolah dengan agroforestry. Namun setelah berumur 18 bulan sampai dengan 24 bulan, pertumbuhan tinggi ter-baik bila jabon dipupuk dengan pupuk kandang $2 \mathrm{~kg} /$ batang dan diolah dengan agroforestry. Pengaruh perlakuan agroforestry dan pemupukan terhadap pertumbuhan tinggi pada setiap pengukuran menunjukkan kecenderungan pertumbuhan yang meningkat (Gambar 4).

Pada Gambar 4, jelas terlihat bahwa pola pertum-buhan tinggi jabon bila hanya dipupuk dengan pupuk kandang sebanyak $2 \mathrm{~kg} / \mathrm{batang}$ mengalami pertumbuhan tinggi yang lebih rendah dan rata-rata tinggi di umur 2 tahun adalah $100 \mathrm{~cm}$. Hal ini berbeda jika jabon ditanam dengan pola agrofo-restry saja dan tidak perlu dipupuk dengan pupuk kandang. Pada umur 2 tahun, tinggi jabon sudah mencapai $400 \mathrm{~cm}$. Bila jabon dipupuk dengan pu-puk kandang 2 $\mathrm{kg} /$ batang dan diolah tanahnya de-ngan pola agroforestry, maka tinggi jabon pada umur 2 tahun mencapai $500 \mathrm{~cm}$.

\section{B. Pembahasan}

Diameter adalah garis lurus yang melewati pusat lingkaran dan bertemu pada setiap batas akhir atau permukaan (Husch et al., 2003). Pengukuran diameter penting dilakukan karena diameter merupakan salah satu dimensi dapat diukur secara langsung dari suatu area permukaan dan menduga volume. Dalam inventarisasi hutan, diameter dapat diduga atas dua yakni diameter dengan kulit dan diameter tanpa kulit. Husch et al., (2003) mendefenisikan tinggi sebagai jarak linier suatu obyek normal terhadap permukaan bumi atau beberapa datum lainnya. Tinggi pohon merupakan suatu terminologi yang belum jelas karena tidak dapat ditentukan secara tepat. Kedua parameter ini merupakan variabel penting yang menentukan volume pohon dan nilai ekonomi usaha di sektor kehutanan.

Upaya untuk meningkatkan besaran diameter dan tinggi pohon terus dilakukan mulai dari awal penanaman dan pemeliharaan. Terdapat beberapa upaya untuk meningkatkan besaran dimensi pohon antara lain dengan pemupukan dan penjarangan. Pemupukan dilakukan untuk memenuhi kebutuhan hara pohon. Fisher dan Binkley (2000) dalam Mindawati (2011) menyebutkan bahwa tanaman Eucaliptus fauciflora yang diberi pupuk $\mathrm{P}$ dosis $500 \mathrm{~kg} / \mathrm{ha}$ dapat meningkatkan produksi kayu sebesar 30\%. Mindawati (2011) menyebutkan bahwa hara di HTI terus menurun bila tidak dilakukan pemupukan secara berkala. Jumlah hara yang diserap tegakan selama 5 tahun tegakan tumbuh sebesar $1.152 \mathrm{~kg} \mathrm{~N} / \mathrm{ha}, 204 \mathrm{~kg} \mathrm{P} / \mathrm{Ha}$, $1.845 \mathrm{~kg} \mathrm{~K} / \mathrm{ha}, 610 \mathrm{~kg} \mathrm{C} / \mathrm{ha}$ dan $83 \mathrm{~kg} \mathrm{Mg} / \mathrm{ha}$ pada rotasi 1 dan $1.106 \mathrm{~kg} \mathrm{~N} / \mathrm{ha}, 240 \mathrm{~kg} \mathrm{P} / \mathrm{Ha}, 1798 \mathrm{~kg}$ $\mathrm{K} / \mathrm{ha}, 466 \mathrm{~kg} \mathrm{C} /$ ha dan $88 \mathrm{~kg} \mathrm{Mg} /$ ha pada rotasi 2 . Dari informasi ini maka untuk mendapatkan hasil pertumbuhan tegakan yang optimal maka perlu pemupukan.

Pemupukan dapat berupa pupuk organik dan anorganik. Suriadikarta dan Simanungkalit (2006) menyatakan bahwa pemupukan dengan pupuk organik tidak difokuskan pada penyediaan hara tanah yang dapat diserap tanaman jabon, melainkan untuk memperbaiki sifat fisik, kimia dan biologi tanah sehingga memudahkan tanaman jabon dalam menyerap hara yang tersedia di tanah. Ketika hara yang tersedia di tanah sangat kecil dan tidak diikuti dengan pola pengelolaan lahan seperti agroforestry, maka input hara yang diterima jabon akan sangat rendah dan mempengaruhi pertumbuhannya.

Pemupukan dengan kompos maupun pupuk organik seperti NPK berpengaruh nyata terhadap pertumbuhan jabon. Mansur dan Surahman (2011) menjelaskan bahwa perlakuan pupuk NPK deng-an dosis $100 \mathrm{~g}$ menghasilkan rata-rata pertum-buhan diameter yang paling besar yaitu $8,12 \mathrm{~cm}$ jika dibandingkan dengan perlakuan lainnya. Pertumbuhan jabon tanpa Pupuk NPK mengha-silkan rata-rata pertumbuhan diameter terkecil yaitu $6,67 \mathrm{~cm}$ sedangkan bila diberi pupuk NPK dengan dosis $150 \mathrm{~g}$ menghasilkan rata-rata pertumbuhan diameter sebesar $6,99 \mathrm{~cm}$. Sementara pemberian pupuk kompos seperti kompos batang pisang akan memperbaiki struktur tanah sehing-ga memacu pertumbuhan 
anakan jabon (Wulandari et al., 2011). Sedangkan dalam penelitian ini, tinggi tanaman jabon yang dipupuk dengan pu-puk kompos dan tanahnya diolah dengan sistem agroforestry pada umur 2 tahun mencapai 3,5 m lebih baik jika jabon hanya diberi pupuk kompos saja atau tanahnya diolah dengan agroforestry saja. Hasil penelitian ini menunjukkan pertum-buhan riap yang berbeda dengan hasil penelitian Krisnawati et al. (2011) di Kalimantan Selatan. Hasil tersebut menunjukkan rata-rata riap tinggi adalah antara $0,8-3,7 \mathrm{~m}$, sedangkan hasil penelitian ini menunjukkan rata-rata riap tinggi berkisar antara $1,15-1,60 \mathrm{~m}$.

Pengaruh kompos yang nyata terhadap pertumbuhan semai jabon disebabkan oleh kemampuan pupuk organik untuk memperbaiki struktur dan tekstur tanah, sifat kimia tanah dan mengandung enzim dan hormon yang baik untuk mikroorganisme. Menurut Badrunasar (2012) bahwa terdapat keunggulan dari pupuk kompos, yakni mengandung unsur hara yang lengkap baik makro maupun mikro, mengandung asam humik, fulfik, hormon dan enzim yang baik untuk tanaman dan mikro-organisme, terdapat organisme tanah yang baik untuk memperbaiki sifat biologi tanah, menjaga struktur tanah, penyangga $\mathrm{pH}$ tanah, menjaga kelembaban tanah dan tidak merusak lingkungan. Namun dibalik keunggulan tersebut terdapat beberapa kelemahan pupuk kompos yakni unsur hara yang terkandung sangat kecil, meningkatkan biaya angkut karena kebutuhan yang sangat banyak, dan cenderung membutuhkan biaya investasi yang tinggi dalam pemeliharaan tanaman.

Pupuk organik menurut Peraturan Menteri Pertanian No.2/Pert/HK.060/2/2006 tentang pupuk organik dan pembenah tanah adalah pupuk yang sebagian besar atau seluruhnya terdiri atas bahan organik yang berasal dari tanaman dan atau hewan yang telah melalui proses rekayasa, dapat berbentuk padat atau cair yang digunakan mensuplai bahan organik untuk memperbaiki sifat fisik, kimia dan biologi tanah. Definisi tersebut menunjukkan bahwa pupuk organik lebih ditujukan kepada kandungan C-organik atau bahan organik daripada kadar haranya, nilai C-organik itulah yang menjadi pembeda dengan pupuk anorganik. Bila C-organik rendah dan tidak masuk dalam ketentuan pupuk organik maka diklasifikasikan sebagai pembenah tanah organik. Pembenah tanah atau soil ameliorant menurut SK Menteri Pertanian adalah bahan-bahan sintesis atau alami, organik atau mineral (Sudikarta dan Simanungkalit, 2006).

Pemupukan dengan kompos tentu tidak menjadi satu-satunya cara untuk meningkatkan produktivitas. Produktivitas lahan hutan rakyat dapat dicapai melalui pengkayaan (enhancing) tanaman yang ada di lahan tersebut melalui pola agroforestry. Agroforestry tidak hanya dipahami sebagai penanaman tanaman sela di antara tanaman pokok dalam hal ini jabon. Peran agroforestry adalah memberikan nilai tambah terhadap lahan yang dapat diperoleh petani pada kurun waktu tertentu. Pada saat tutupan tajuk jabon belum luas, maka pola agroforestry dapat dikembangkan dengan menanam sayuran yang membutuhkan cahaya yang tinggi. Dan ketika tutupan tajuk jabon telah menutupi sebagian besar lahan, maka kombinasi tanaman dengan jenis tanaman hortikultura yang tahan hidup di bawah naungan.

Agroforestry juga kini tidak terbatas pada penanaman tanaman semusim di bawah naungan saja melainkan telah berkembang pada pemanfaatan bawah tegakan untuk jenis tanaman kayu keras dan untuk tanaman obat, seperti agroforestry antara kelapa sawit dengan kayu bawang di Bengkulu (Siahaan et al., 2012); produksi pegagan di bawah naungan kopi dan Felmengia (Maretta et al., 2012). Siahaan et al., (2012) menyebutkan bahwa pengembangan perkebunan kelapa sawit dengan pola agroforestry dapat memberikan tambahan keuntungan bagi petani berupa hasil kayu yang nilainya dapat melebihi penurunan produksi sawit. Marreta et al., (2012) menyebutkan bahwa produksi pegagan akan baik bila dipupuk secara bersamaan antara pupuk kandang dan pupuk kimia. Lebih jauh dijelaskan bahwa penerapan pola agroforestry pada budidaya pegagan dengan kopi dan flemengia akan lebih baik bila diberikan pupuk urea $150 \mathrm{~kg} / \mathrm{ha}$, pupuk Sp36 sebanyak 150 kk/ha, KCL sebanyak $150 \mathrm{~kg} / \mathrm{ha}$ dan kompos sebanyak 10 ton/ha.

Pola agroforestry akan memberikan dampak positif bagi pendapatan petani dalam kurun waktu pendek dan menengah. Pendapatan jangka panjang bagi petani adalah setelah jabon dipanen. Selain peningkatan nilai lahan, dampak ekologi yang diperoleh adalah menurunkan laju runoff ketika kondisi tutupan lahan bersih dari gulma dan tanaman penutup tanah (cover crop), meningkatkan infiltrasi dan menahan penambatan zat kimia dari udara yang akan tertimbun di tanah seperti timbal. Dampak sosial yang diterima dari 
kegiatan agroforestry adalah interaksi yang terus menerus dengan lahan mampu merubah budaya kerja petani hutan yang hanya sekali dalam kurun waktu yang lama ke lahan dan cenderung berpindah ke perkotaan untuk mencari pekerjaan dalam memenuhi nafkah sehari-hari dan juga pasokan kebutuhan bahan makanan untuk kebutuhan lokal. Pola ini akan terpenuhi melalui sistem perencanaan lahan yang tepat. Tepat dalam arti sesuai dengan kualitas tempat tumbuh, kondisi ekonomi petani dan situasi sosial seperti budaya kerja yang ada. Semua faktor ini bersifat lokalistik dan tidak dapat dianggap sama pada lokasi yang berbeda. Hal ini ditegaskan oleh Torquebiau (2000) bahwa agroforestry merupakan gabungan antara pohon dengan pertanian yang terus berkembang menjadi disiplin penggunaan lahan.

Pola agroforestry juga berguna dalam pengendalian penyebaran hama penyakit yang menyerang tanaman jabon. Hama yang sering menyerang tanaman jabon bila ditanam dengan pola monokultur dalam skala luas adalah jenis Arthroschista hilaralis (Walker) sinonim dengan Margaronia hilaralis dan Daphnia hilaralis (Nair, 2007). Jenis hama ini menyakit tanaman jabon muda. Bagian pohon yang diserang adalah bagian daun, namun tidak menyebabkan kematian. Pengendalian hama ini dapat dilakukan dengan cara meningkatkan musuh alaminya yakni Cedriaparadoxa, Litomastrix sp. (Encyrtidae), Apanteles balteata (Braconidae), Macrocentrus philippinensis (Braconidae) dan Sympiesis sp. (Eulophidae) (Nair, 2007).

\section{KESIMPULAN}

\section{A. Kesimpulan}

Dari hasil dan pembahasan tersebut di atas dapat diambil beberapa kesimpulan sebagai berikut:

1. Kombinasi antara pupuk kandang $2 \mathrm{~kg} /$ tanaman dan agroforestry akan memberikan respon pertumbuhan diameter yang berbeda bila tanaman jabon dipupuk dengan pupuk kandang sebanyak $2 \mathrm{~kg} /$ tanaman. Namun bila dibandingkan dengan pertumbuhan diameter tanaman jabon yang ditanam dengan pola agroforestry dan tidak diberi pupuk kandang, hasilnya tidak berbedanyata.

2. Pertumbuhan tinggi tanaman jabon setelah diberi pupuk kandang sebanyak $2 \mathrm{~kg} /$ tanaman dan agroforestry akan memberikan dampak pertumbuhan yang lebih tinggi dibandingkan tanaman jabonyang dipupuk dengan pupuk kandang $2 \mathrm{~kg} / \operatorname{tanaman}$ atau tanaman jabon yang ditanam dengan pola agroforestry.

3. Pertumbuhan tanaman jabon akan lebih baik dengan pola agroforestry dimana tanaman agroforestry perlu mendapatkan asupan hara yang seimbang.

\section{B. Saran}

Berdasarkan hasil penelitian dapat disarankan bahwa untuk meningkatkan diameter dan tinggi jabon baiknya dilakukan pemupukan dengan pupuk kandang sebanyak $2 \mathrm{~kg} / \mathrm{ha}$ dan diikuti dengan pola agroforestry. Pemupukan baiknya tidak dilakukan sekali saja namun perlu dilakukan secara berkala.

\section{DAFTAR PUSTAKA}

Badrunasar, A. 2012. Teknik Pembuatan Pupuk Organik. Balai Penelitian Teknologi Agroforestry. Kementerian Kehutanan. Ciamis.

Ekawati S., N. Haryanti dan D. Subaktini. 2005. Efektivitas Kelompok Tani dalam Pengelolaan $\mathrm{Hu}$ tan Rakyat (Study Kasus Hutan Rakyat Wonogiri). Info: 6(2).

Husch, B., T.W. Beers dan J.A. Kershaw Jr. 2003. Forest Mensuration. John Wiley \& Sons. New Jersey.

Kementerian Kehutanan. 2011. Peraturan Menteri Kehutanan RI No.P. 49/Menhut-II/2011 tentang Rencana Kehutanan Tingkat Nasional tahun 2011-2030. Jakarta.

Kementerian Pertanian. 2006. Peraturan Menteri PertanianNo. 02/Pert/HK.060/2/2006 tentang Pupuk Organik dan Pembenah Tanah. Jakarta

Krisnawati H., M. Kallio dan M. Kanninen. 2011. Anthocephalus cadamba Miq: Ekologi, Silvikultur dan Produktivitas. CIFOR. Bogor. Indonesia.

Mansur, I. dan Surahman. 2011. Respon Tanaman Jabon (Anthocephalus cadamba) terhadap Pemupu-kan Lanjutan (NPK). Jurnal Silvikultur Tropika: 3(1): 71-77.

Maretta, D., D. Iskandar dan A. Arianto. 2012. Kajian Optimasi Dosis Pupuk Kandang dan Kimia Pada Produksi Pegagan (Centella asiatica (L) Urban) Di Bawah Naungan Tanaman Kopi dan Flemengia Dengan Pola Agroforestry. Prosiding: Seminar Nasional Agroforestry III. Yogyakarta: 29 Mei 2012.

Martawidjaya A., Iding K., Y.I.Mandang, Soewanda A.P dan Kosasi K. 1989. Atlas Kayu Indonesia 
Jilid II.Badan Litbang Kehutanan Indonesia. Bogor.

Mattjik,A.A. dan I.M. Sumertajaya. 2006. Perancangan Percobaan: Dengan Aplikasi SAS dan Minitab. IPB PRESS. Bogor.

Mindawati, N. 2011. Kajian Kualitas Tapak Hutan Tanaman Industri Hibrid Eucalyptus urograndis sebagai Bahan Baku Industri Pulp dalam Pengelolaan Hutan Lestari. Disertasi. Pascasarjana Institut Pertanian Bogor. Bogor.

Nair, K.S.S. 2007. Tropical Forest Insect Pest: Ecology, Impact and Management. Cambridge University Press.New York.

Siahaan, H., A. Sumadi dan A.W. Nugroho. 2012. Pengaturan Optimalisasi Lahan Melalui Agroforestry Antara Tanaman Kehutanan dengan Sawit. Prosiding: Seminar Hasil Penelitian
Balai Penelitian Kehutanan Palembang. Palembang, 23 Oktober 2012.

Suriadikarta, D.A. dan R.D.M. Simanungkalit. 2006. Pupuk Organik dan Pupuk Hayati. Editor: R.D.M. Simanungkalit, Didi Ardi Suriadikarta, Rasti Saraswati, Diah Setyorini dan Wiwik Hartatik. Balai Besar Litbang Sumberdaya Lahan Pertanian Badan Penelitian dan Pengembangan Pertanian. Bogor.

Torquebiau, E.F. 2000. A Renewed Prespective on Agroforestry Concepts and Classification. Jurnal Comptes Rendus de I'Academie des Science. Vol. 323: 1009-1017.

Wulandari, A.S., I. Mansur dan H. Sugiarti. 2011. Pengaruh Pemberian Kompos Batang Pisang terhadap Pertumbuhan Semai Jabon (Anthocephalus cadamba Miq.). Jurnal Silvikultur Tropika: 3 (1) : 78-81. 